pISSN : 1979-0694

\title{
APLIKASI PERHITUNGAN PAYROLL DOSEN PADA STMIK DUMAI
}

\author{
Putri Yunita \\ Sekolah Tinggi Manajemen Informatika Dan Komputer (STMIK DUMAI) \\ Jl. Utama Karya Bukit Batrem, Kota Dumai - Riau \\ Email : yu_pi19@yahoo.com
}

\begin{abstract}
ABSTRAK
Pengelolaan sumberdaya manusia yang tepat akan memberikan kontribusi yang optimal bagi perusahaan/lembaga. Unsur yang utama dalam mengelola sumberdaya manusia dengan menerapkan kebijaksanaan kompensasi berupa gaji. Aktivitas penggajian merupakan pekerjaan yang memerlukan ketelitian tinggi. Jika aktivitas dilakukan dengan menggunakan Microsoft Excel memerlukan waktu lama, karena tidak menyimpan data dalam basisdata. Namun kenyataannya sistem penggajian yang sedang berjalan pada STMIK Dumai masih menggunakan Microsoft Excel. Hal ini menyebabkan keterlambatan dalam memproses penggajian, dikarenakan sering terjadi kesalahan dalam menghitung jumlah gaji dosen yang didasarkan berbagai rincian yang berbeda. Merancang dan mengimplementasikan aplikasi yang dikembangkan dalam pengolahan data dengan menggunakan bahasa pemograman Visual Basic 6.0 dan database MySql. Hasil penelitian ini menunjukkan bahwa proses pengolahan data secara komputerisasi cenderung lebih mudah dan pengolahan mempunyai tingkat akurasi lebih baik dari pada menggunakan cara manual. Dalam hal informasi, laporan yang dibuat cenderung lebih mudah dan cepat karena secara otomatis sesuai dengan data inputan yang dimasukkan sebelumnya.
\end{abstract}

Kata Kunci : aplikasi, penggajian, dosen

\section{PENDAHULUAN}

Pengelolaan sumber daya manusia yang tepat akan memberikan kontribusi yang optimal bagi perusahaan/lembaga maupun instansi. Unsur yang utama dalam mengelola sumberdaya manusia adalah dengan menerapkan kebijaksanaan kompensasi yang berupa gaji. Aktivitas penggajian merupakan pekerjaan yang memerlukan ketelitian tinggi. Jika aktivitas ini dilakukan dengan menggunakan Microsoft Excel memerlukan waktu lama, karena Microsoft Excel penggunaannya kurang user friendly dan tidak menyimpan data dalam basis data.

STMIK Dumai merupakan salah satu perguruan tinggi yang ada di kota dumai, dimana dalam pengolahan penggajian karyawan masih menggunakan Microsoft Excel dalam proses perhitungan nya. Hal ini menyebabkan munculnya beberapa permasalahan diantaranya penetapan honor dosen persks menjadi rancu berdasarkan jenjang pendidikan yang belum ada data master dalam penentuannya, sering terjadinya kekeliruan dalam perhitungan jumlah tatap muka yang akan dibayar dengan tatap yang telah dibayar sebelumnya, serta penentuan transpotasi dosen yang berdasakan status dosen tersebut, kesulitan dalam hal perekapan honor dosen pertahun ajaran, honor yang di dapat per masing-masing dosen dan laporan-laporan yang dibutuhkan lainnya.

Adapun beberapa masalah yang terjadi tentunya dapat menyebabkan keterlambatan pembuatan laporan yang dibutuhkan dalam waktu yang singkat. Oleh karena itu diperlukan sebuah aplikasi dimana dapat mengatasi masalah yang terjadi. Dengan adanya aplikasi ini dapat mempermudah bagian keuangan dala aktivitas nya. Dan juga dapat mengurangi kemungkinan kesalahan maupun kekeliruan dalam peritungan honor dosen serta dengan mudah untuk mendapatkan informasi-informasi yang dibutuhkan.

Gaji dan upah adalah sejumlah uang yang dibayarkan kepada karyawan sebagai imbalan jasa yang diberikannya selama suatu periode tertentu, Dunia (Devi Tri Rahayu etnaningtyas 2015: 2-3).

Aplikasi adalah program siap pakai yang dapat digunakan untuk mejalankan perintahperintah dari pengguna aplikasi tersebut dengan 
I N F ORMA T IK

Jurnal Informatika, Manajemen dan Komputer, Vol. 10 No. 1, Mei 2018

eISSN : 2580-3042

pISSN : 1979-0694

tujuan mendapatkan hasil yang lebih akurat sesuai dengan tujuan pembuatan aplikasi tersebut, aplikasi mempunyai arti yaitu pemecah masalah yang menggunakan salah satu tehnik pemprosesan data aplikasi yang biasa berpacu pada sebuah komputansi yang diinginkan atau diharapkan maupun pemprosesan data yang diharapkan. (Hasan Abdurahman \& Asep Ririh Riswaya, 2014:h.62).

Sistem adalah kumpulan dari elemen-elemen yang berinteraksi untuk mencapai suatu tujuan tertentu (Prof. Dr. Jogiyanto HM, MBA., 2009:h.1). Pendekatan sistem yang merupakan kumpulan dari elemen-elemen atau komponenkomponen atau subsistem-subsistem merupakan definisi yang lebih luas. Defenisi ini lebih banyak diterima, karena kenyataannya suatu sistem data terdiri dari beberapa subsistem atau sistem-sistem bagian (Prof. Dr. Jogiyanto HM, MBA., 2009:h.2).

\section{METODE PENELITIAN}

Kerangka penelitian yang di gunakan dalam penelitian ini adalah sebagai berikut :

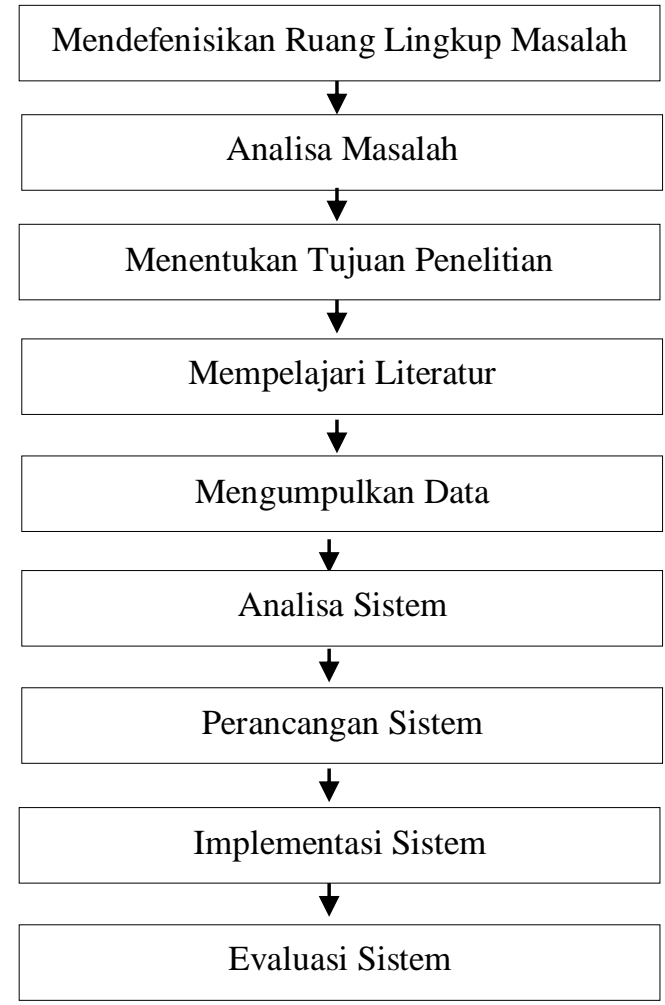

Gambar 1. Kerangka penelitian

\section{HASIL DAN PEMBAHASAN}

A. Context Diagram

Sistem yang sedang berjalan pada aplikasi perhitungan payroll dosen STMIK Dumai dapat dilihat pada gambar Context Diagram sebagai berikut :

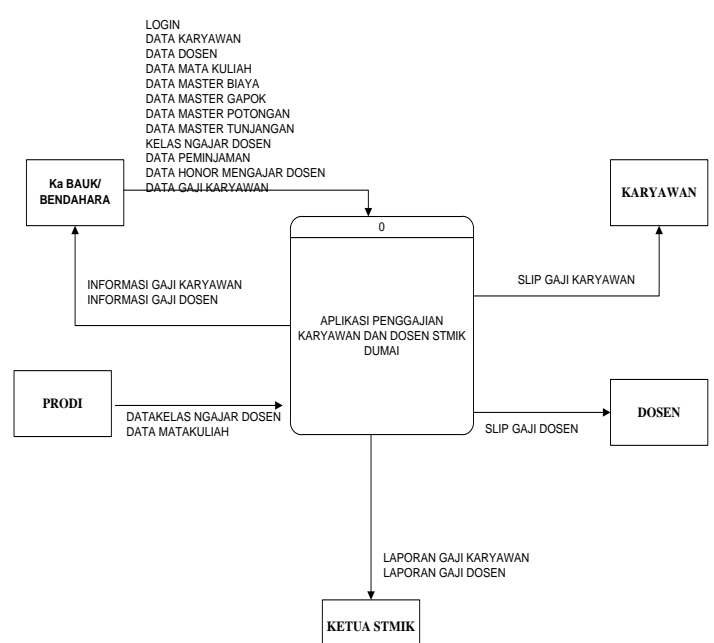

Gambar 2. Context Diagram

\section{B. Data Flow Diagram}

DFD menunjukkan hubungan antara data pada sistem dan proses pada aplikasi perhitungan payroll dosen STMIK Dumai dapat dilihat pada gambar DFD sebagai berikut :

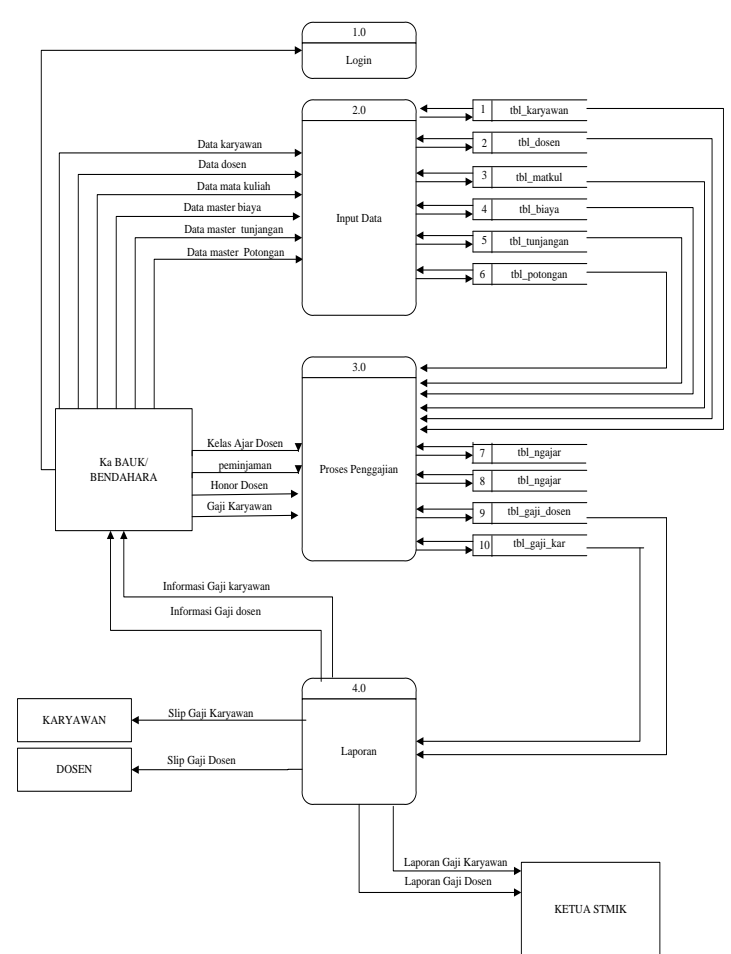

Gambar 3. Data Flow Diagram 
I N F ORMA T IK

Jurnal Informatika, Manajemen dan Komputer, Vol. 10 No. 1, Mei 2018

eISSN : 2580-3042

pISSN : 1979-0694

\section{Implementasi Sistem}

Langkah-langkah dan cara dalam melakukan implementasi sistem yang terdiri dari layout program, aplikasi, petunjuk pengoperasian program, pembuatan program. Tahap implementasi merupakan tahap meletakkan sistem agar dalam proses pengolahan data serta informasi pada perekaman data selalu siap di operasikan. Tahap ini juga termasuk kegiatan menulis kode program.

\section{Login}

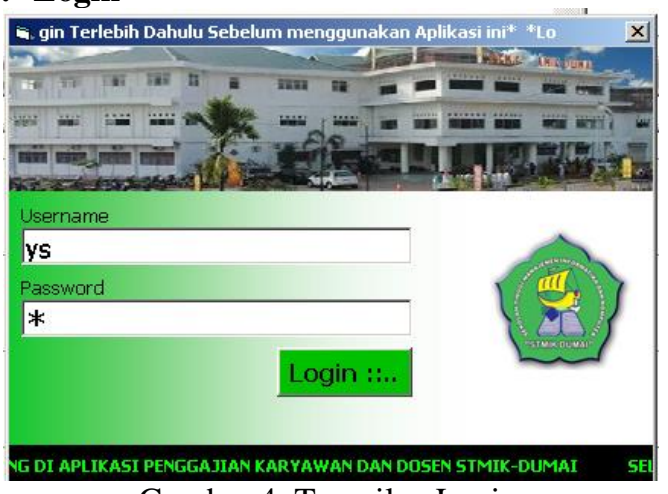

Gambar 4. Tampilan Login

\section{Menu Utama}

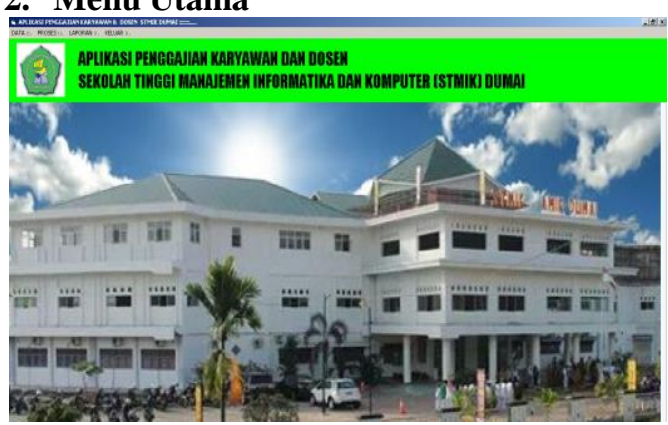

Gambar 5. Tampilan Menu Utama

\section{Data Dosen}

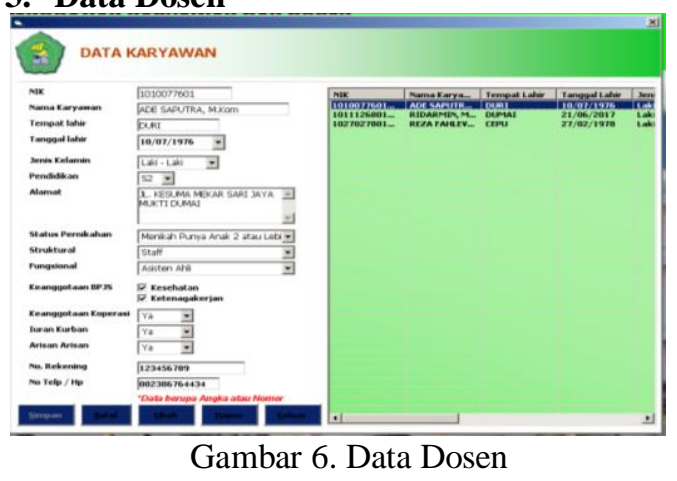

\section{Data Master Honor}

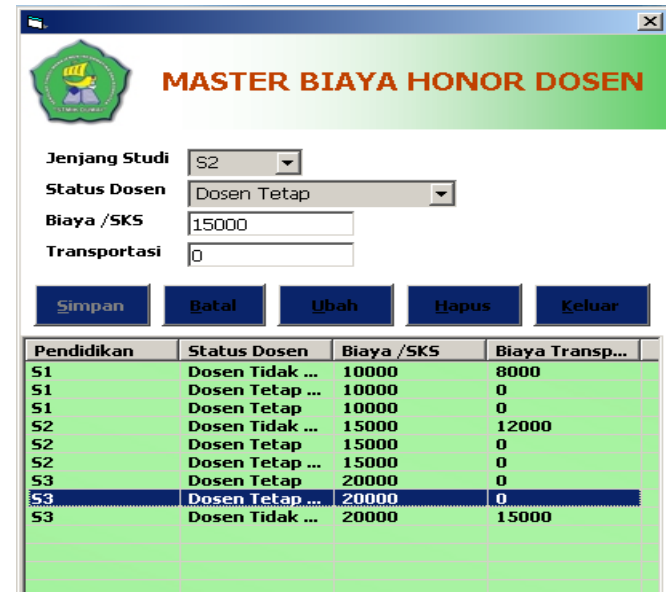

Gambar 7. Data Master Honor

\section{Data Penggajian}

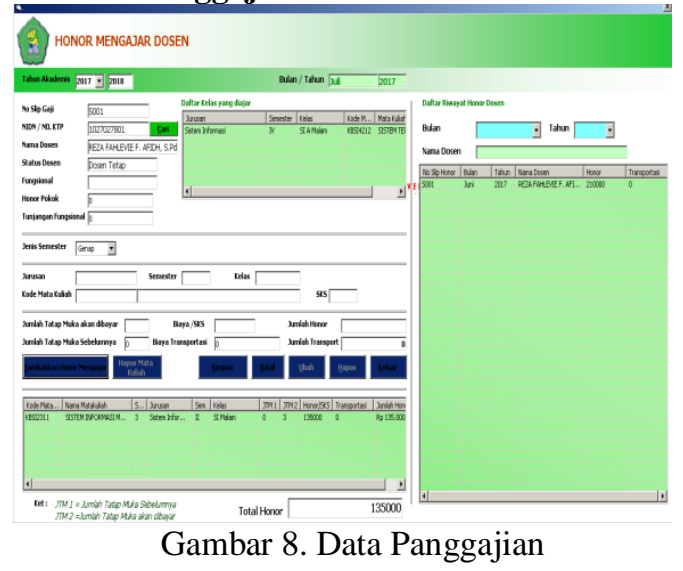

6. Laporan

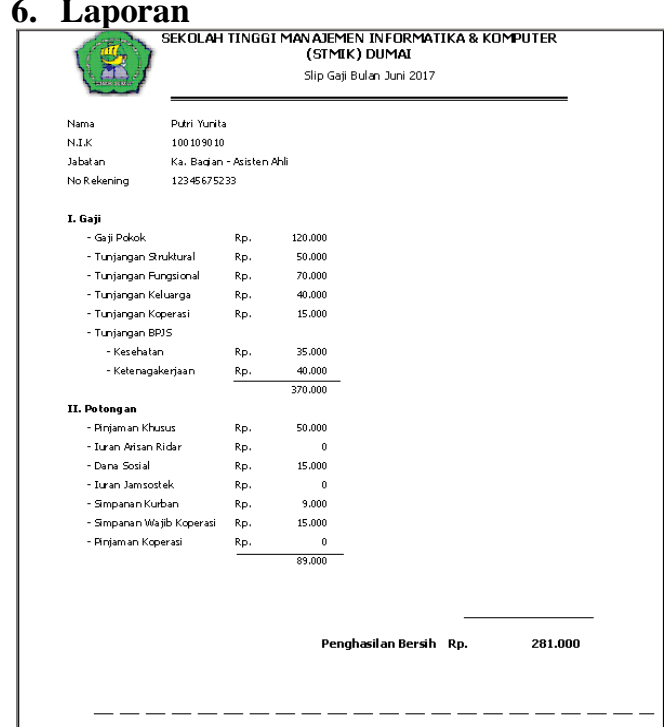

Gambar 9. Laporan Slip Gaji 


\section{Laporan Rekap Gaji}

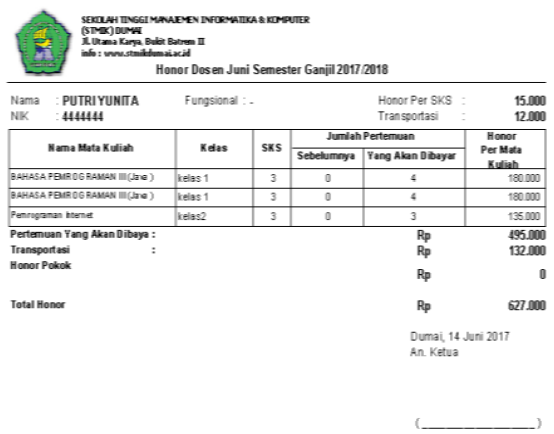

Gambar 10. Laporan Rekap Gaji
Megawaty. (2013) Sistem Penggajian Dosen

Universitas Bina Darma Menggunakan Metode Ood (Object Oriented Design), Jurnal Ilmiah MATRIK Vol.15 No.3

Ahmad Reza Fahlevi. (2013) Sistem Informasi

Penggajian Program Diploma Komputer Universitas Sriwijaya, Jurnal Generic, Vol. 8, No. 1, Maret 2013.

\section{SIMPULAN}

Dari hasil penelitian yang lakukan dapat kesimpulan dari analisa diantaranya sebagai berikut:

1. Aplikasi ini dapat menghasilkan data yang cepat dan untuk memperkecil kesalahan dalam proses penggajian.

2. Data tersusun rapi dalam database membuat proses penggajian lebih cepat, serta pengendalian laporan akan lebih mudah dan cepat waktu.

3. Dengan dibangunnya aplikasi penggajian ini dapat memudahkan bendahara/Ka BAUK dalam proses penggajian.

\section{REFERENSI}

Devi Tri Rahayu Retnaningtyas, Moch. Dzulkirom A.R, Muhammad Saifi. (2015). Analisis Sistem Dan Prosedur Penggajian Dan Pengupahan Dalam Upaya Mendukung Pengendalian Intern Perusahaan (Studi Kasus Pada Perusahaan Kacang Shanghai "Gangsar" Ngunut Tulungagung). Jurnal Administrasi Bisnis (JAB)| Vol. 1 No. 1

Arie Widya Saputra, Imam Bukhori. (2014) Perancangan sistem informasi penggajian Pada Sekolah Menengah pertama (SMP) PGRI Kebonagung, Indonesian Journal on Networking and Security - Volume 3 No 3.

Sulung Yogy Hardhanto, David Paul Elia Saerang dan Harijanto Sabijono. (2015) Analisis Sistem Pengendalian Intern Penggajian Karyawan Pada Pt. Bpr Prisma Dana, Jurnal Berkala Ilmiah Efisiensi Volume 15 No. 05 